\title{
HEALTH EDUCATION DAN PROMOSI KESEHATAN: THALASEMIA DAN DETEKSI DINI THALASEMIA MELALUI PRE MARITAL CEK UP BAGI REMAJA
}

\author{
Umi Hanik Fetriyah ${ }^{1 *}$, Malisa Ariani ${ }^{2}$, Yunina Elasari ${ }^{3} \&$ Paul Joae Brett Nito $^{4}$ \\ 1,3Program Studi Sarjana Keperawatan, Fakultas Kesehatan, Universitas Sari Mulia, \\ Banjarmasin, Indonesia \\ 1,3Program Studi Profesi Ners, Fakultas Kesehatan, Universitas Sari Mulia, \\ Banjarmasin, Indonesia \\ *email: umi_hanik_f04@yahoo.co.id
}

\begin{abstract}
ABSTRAK
Thalasemia merupakan salah satu kelainan genetik hematologi yang umum ditemukan di Indonesia. Penyakit ini tidak dapat disembuhkan, diturunkan secara resesif dan menyebabkan morbiditas dan mortalitas serta menimbulkan beban ekonomi yang berat pada masyarakat. Angka kejadian Thalasemia cenderung mengalami peningkatan setiap tahunnya termasuk di Banjarmasin. Pentingnya upaya strategi pencegahan Thalasemia dimulai sedini mulai dari remaja sangat diperlukan, salah satunya melalui pemberian edukasi dan promosi kesehatan mengenai Thalasemia dan deteksi dini sebelum menikah bagi remaja sehingga dapat berkontribusi mengurangi dan mencegah kejadian Thalasemia. Oleh karena itu pengabdi berupaya memecahkan masalah dengan melakukan health education pada remaja mengenai penyakit Thalasemia dan promosi kesehatan deteksi dini Thalasemia sebelum nikah. Tim pengabdi melaksanakan kegiatan pemberian edukasi mengenai Thalasemia dan promosi kesehatan screening sebelum menikah (pre marital medical cek up) bagi masyarakat di wilayah Banjarmasin khususnya remaja melalui webinar di media sosial yakni live streaming instagram dan wa gruop sebanyak 2 kali kegiatan edukasi dan promosi kesehatan. Hasilnya sebanyak 22 remaja telah mengikuti webinar health education mengenai penyakit Thalasemia dan promosi kesehatan mengenai pencegahannya salah satunya dengan deteksi dini Thalasemia sebelum nikah. Sebesar 100\% remaja mengikuti kegiatan dua kali webinar mengalami peningkatan pengetahuan penyakit Thalasemia dan pencegahannya melalui screening deteksi dini sebelum menikah. Nilai rata-rata peningkatan nilai post test sebesar 14,45. Sebagian besar menyatakan puas terhadap kegiatan pengabdian masyarakat. Kesimpulan kegiatan pengabdian kepada masyarakat ini remaja mengalami peningkatan pengetahuan, hal ini berkontribusi mengurangi kejadian Thalasemia dan pentingnya pendidikan kesehatan dan promosi kesehatan pada masyarakat khususnya remaja sebagai calon orang tua tentang Thalasemia dan deteksi dini Thalasemia sebelum nikah yang harapannya dapat melahirkan generasi penerus bangsa yang sehat.
\end{abstract}

Kata Kunci : Health Education, Pre Marital Cek up, Promosi Kesehatan, Remaja, Thalasemia

\section{A. PENDAHULUAN}

Thalasemia merupakan penyakit anemia hemalitik dimana terjadi kerusakan sel darah merah di dalam pembuluh darah sehingga umur eritrosit menjadi pendek (kurang dari 100 hari). (Ngastiyah, 2013).

Thalasemia merupakan penyakit anemia hemolitik herediter yang diturunkan secara resesif. (Mansjoer, 2014). 
Seseorang terdiagnosis

Thalasemia bisa mulai sesorang berusia 3- 18 bulan tergantung dari klasifikasi Thalasemia (Thalasemia Mayor atau Minor) dan cepat atau lambatnya dibawa ke pelayanan kesehatan (Susanto, 2020). Anak usia sekolah yang mengalami thalassemia memiliki kualitas hidup yang rendah karena mengalami perubahan fisik yang berbeda dengan anak normal lainnya dan penurunan aktifitas fisik. Keterbatasan fisik dialami anak yang mengalami thalassemia menyebabkan munculnya berbagai masalah keadaan fisik yang lemah karena komplikasi penyakit karena anak harus menjalani pengobatan dan transfusi darah seumur hidup. Akibatnya anak akan mengalami perubahan fisik yang beresiko gangguan pertumbuhan dan perkembangan anak. Proses belajar anak karena kondisi kesehatan yang menurun maka anak lebih sering absen sekolah, dan penurunan performa sekolah. Anak terdiagnosis thalassemia juga mengalami perubahan psikologi, emosional yang meningkat, putus asa, rasa malu akibat perubahan fisik sehingga berpotensi anak mengalami kesulitan bersosialisasi dan bahkan depresi (Apsari, 2016; Jafari-Shakib et al, 2016; Purba, Nency dan Faria, 2019; Arian et al, 2020).

Tatalakasana pada anak dengan thalassemia memerlukan perhatian tenaga kesehatan dengan melakukan Tindakan pencegahan primer, sekunder dan tersier. Salah satunya yakni berperan dalam berupaya menyusun strategi pencegahan penyakit Thalassemia, termasuk perawat, dokter dan tenaga kesehatan lainnya karena tenaga kesehatan berperan sebagai penyampai informasi mengenai kesehatan kepada masyarakat mulai dari bayi, anak, remaja , dewasa sampai lansia (Tursinawati \& Fuad, 2018).

Hasil rekomendasi penelitian sebelumnya menyatakan pentingnya pemberian edukasi atau pendidikan kesehatan mengenai penyakit talasemia dan pengobatan serta perawatan bagi pasien dengan thalassemia dan keluarganya guna peningkatkan kualitas hidup dan kesejahteraan klien. Pemerintah United Emirat Arab telah memiliki 
program nasional tahun 2008 untuk mempromosikan skrining pranikah yang memberikan konseling genetik untuk pasangan non-berisiko. Meskipun berbagai tindakan program skrining pranikah thalassemia bagi calon pasangan suami istri guna meningkatkan kesadaran tentang penyakit Thalasemia dan meningkatkan kesadaran masyarakat, mengurangi perkawinan yang membawa gen carier Thalsemia dan mengurangi kejadian Thalasemia (Angastiniotis dan Lobitz, 2019; Arian et al, 2020; Shivappa et al, 2021).

Pemberian edukasi kesehatan (health education) mengenai penyakit Thalasemia dan promosi kesehatan screening sebelum menikah (pre marital medical cek up) bagi masyarakat khususnya remaja yang belum menikah atau akan menikah sehingga dengan adanya peningkatan pengetahuan mengenai Thalasemia dan promosi kesehatan deteksi dini cek kesahatan sebelum pernikahan bagi remaja dapat juga meningkatkan sikap terhadap thalassemia dan meningkatkan perilakunya atau melakukan tindakan pencegahan melalui deteksi dini pemeriksaan diri remaja sebelum memutuskan menikah dengan pasangannya bahwa mereka sehat atau tidak membawa bibit karier Thalasemia sehingga dapat menikah karena tidak beresiko memiliki keturunan Thalasemia. Hal ini didukung dengan hasil penelitian Tursina dan Fuad (2018) bahwa ada hubungan yang signifikan $(\mathrm{P}=0,023)$ antara sikap dengan pengetahuan tentang Thalasemia dan ada hubungan anatara tindakan dengan pengetahuan mengenai Thalasemia ( $\mathrm{p}=0,039)$. Mahasiswa (berusia 18 tahun ke atas) atau remaja akhir atau dewasa muda memiliki pengetahuan tentang Thalasemia, maka mereka juga memiliki sikap dan tindakan atau perilaku yang baik tentang pencegahan penyakit Thalasemia, artinya tingkat pengetahuan mempengaruhi sikap dan tindakan pencegahan Thalasemia.

Berdasarkan permasalahan tersebut maka pengabdi memutuskan untuk melakukan kegiatan pengabdian masyarakat berupa health education pada remaja mengenai penyakit Thalasemia dan promosi kesehatan 
deteksi dini Thalasemia sebelum nikah yang ditujukan bagi masyarakat luas terutama remaja yang berada di wilayah Banjarmasin. Harapannya dapat berkontibusi dalam meningkatkan pengetahuan masyarakat dalam kegiatan primer upaya kesehatan melalui kegiatan pemberian Pendidikan kesehatan dan promosi kesehatan dapat mengurangi kejadian Thalasemia pada anak sebagai calon generasi bangsa.

\section{B. METODE}

Metode pelaksanaan kegiatan pengabdian masyarakat dibagi menjadi tiga tahap, yaitu persiapan, pelaksanaan, dan evaluasi. Tahapan persiapan meliputi pendekatan kepada beberapa guru sekolah menengah pertama, sekolah menegah atas di wilayah Banjarmasin dan institusi Pendidikan untuk perizinan terkait penyelenggaraan kegiatan PkM. Tahap persiapan dilakukan diskusi dan merumuskan permasalahan yang saat ini mengalami kecenderungan kenaikan kejadian Thalasemia dan mencari solusinya, salah satunya yang ditempuh dengan kegiatan PkM ini.

Tahap pelaksanaan meliputi kegiatan pemberian pendidikan kesehatan dan promosi kesehatan oleh tim pengabdi dan didampingi oleh fasilitator yang dilaksanakan dua kali yakni tanggal 6 Maret 2021 dan 13 Maret 2021 melalui webinar zoom dan pendampingan melalui media whatsap. Kendala saat pelaksanaan kegiatan yang dihadapi oleh pengabdi adalah sulitnya mengumpulkan sasaran Pkm yang tepat waktu dan mau untuk mengikuti proses pkm yang dilakukan sebanyak dua kali sehingga untuk penyampaian materi dibagi menjadi dua kali dan disertai dengan kuis dan evaluasi serta pembagian doorprize bagi yang aktif dalam kegiatan Pkm. Pencapaian program pengabdian masyarakat yang dilaksanakan ini mengacu kepada rencana kegiatan yang telah disusun dalam proposal. Evaluasi atas program yang telah dilaksanakan yakni terlaksananya kegiatan pemberian edukasi mengenai Thalasemia dan promosi kesehatan screening sebelum menikah (pre marital medical cek 
up) bagi masyarakat di wilayah

Banjarmasin khususnya remaja melalui webinar di media sosial yakni live streaming instagram dan wa gruop sebanyak 2 kali kegiatan edukasi dan promosi kesehatan, poster dan leafleat mengenai kegiatan terseut juga dibagikan melalui group whatsapp. Evaluasi kegiatan dilakukan melalui observasi saat kegiatan berlangsung, pre test (mengisi google form), post test (mengisi google form), wawancara mengenai materi yang telah disampaikan pemateri. Evaluasi akhir kegaitan dilakukan untuk mengukur pengetahuan para remaja yang mengikuti kegiatan Pkm. Hasil evaluasi untuk menentukan rencana tindak lanjut untuk kegiatan $\mathrm{Pkm}$ dikemudian hari.

\section{HASIL DAN PEMBAHASAN}

Hasil kegiatan dari PkM yang telah dilakukan selama dua kali kegiatan pada remaja tentang pemberian edukasi mengenai Thalasemia dan promosi kesehatan screening sebelum menikah (pre marital medical cek up) diuraikan pada tabel 1 .

\section{Tabel 1.1 Hasil Kegiatan PKM}

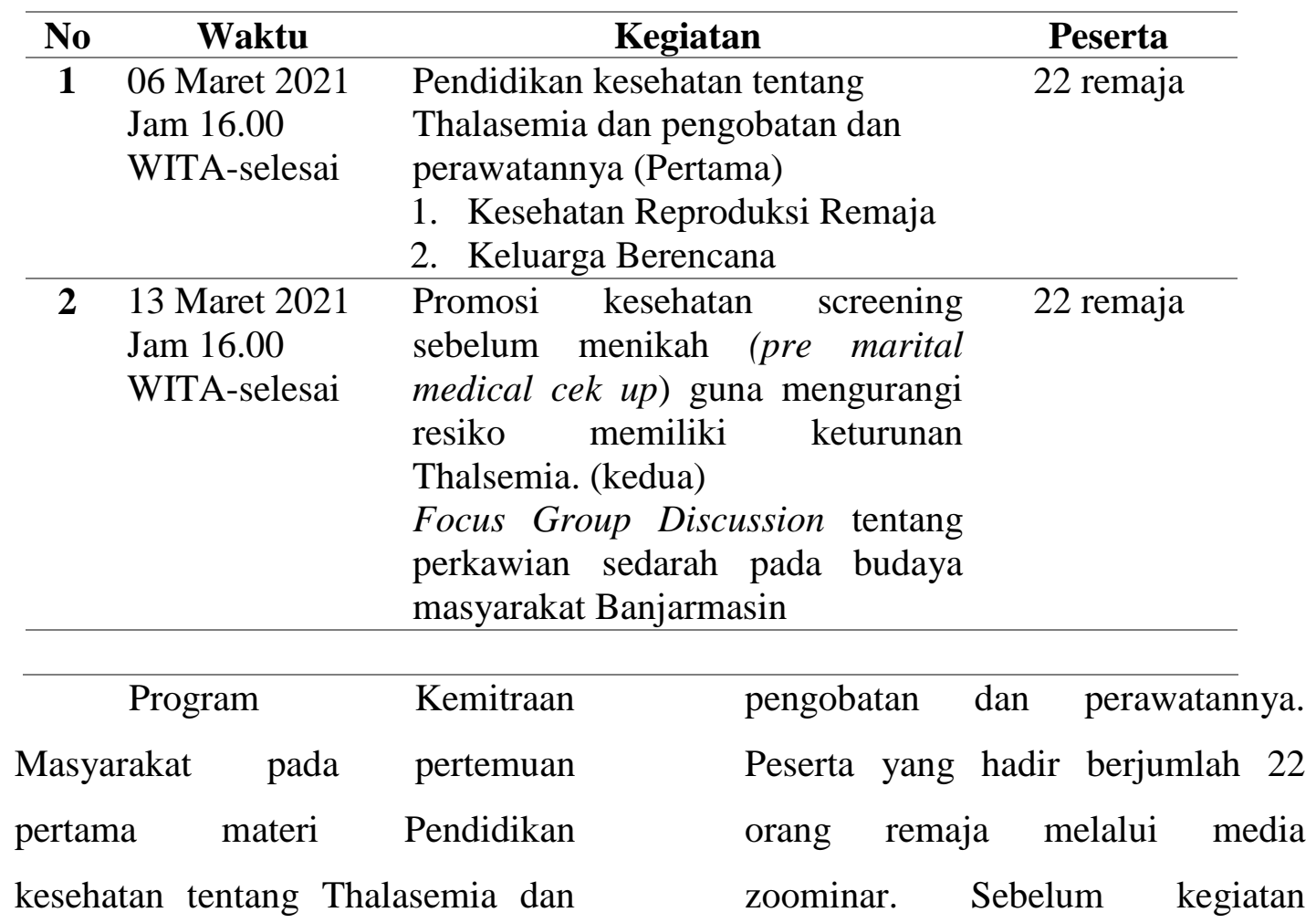


dilakukan pre test (mengisi google form), dan setelah zoominar pertama berakhir dilakukan post test secara lisan. Hasilnya ada peningkatan pengetahuan dari para peserta sesudah mengikuti zoominar yang pertama mengenai pengertian Thalasemia dan tanda gejala beserta komplikasinya.

Peserta memperhatikan dan tampak antusias mengikuti acara pelatihan sampai selesai dibuktikan dengan banyaknya pertanyaan dan aktif saat sesi evaluasi secara lisan saat post test setelah pemberian materi.

Program Kemitraan

Masyarakat pada pertemuan kedua ialah Promosi kesehatan screening sebelum menikah (pre marital medical cek up) guna mengurangi resiko memiliki keturunan Thalsemia. Focus Group Discussion tentang perkawian sedarah pada budaya masayarakat Banjarmasin yang dihadiri oleh 22 orang remaja. Sesudah kegiatan dilakukan evaluasi menggunakan google form dan secara lisan terhadap materi yang telah disampaikan baik materi pertama maupun kedua. Hasilnya ada peningkatan pengetahuan dari para peserta sesudah mengikuti kegiatan zoominar. Nilai rata-rata peningkatan nilai post test sebesar 14,45 . Sebagian besar menyatakan puas terhadap kegiatan pengabdian masyarakat. Nilai pre test tertinggi dengan nilai 100 sebanyak 3 orang dan nilai terendah sebesar 26 sebanyak 1 orang. Nilai rata-rata pre test dari 22 remaja sebesar 69, 68 . Nilai post test yang didapatkan peserta dengan nilai tertinggi 100 sebanyak 9 orang dan nilai terendah sebesar 46 sebanyak 1 orang, dan nilai rat-rata post test sebesar 69, 68 . Hasil observasi peserta dapat menjawab pertanyaan dari fasilitator saat diakhir sesi pertemuan pertama dan kedua dengan antusias.

Hasil Pkm ini sesuai dengan target yang diharapkan yakni terjadinya peningkatan pengetahuan secara kognitif. Hasil penelitian lainnya juga menunjukkan pada kelompok remaja yang diberikan pendidikan kesehatan tentang Thalasemia juga menunjukkan niat untuk menjalani skrining secara signifikan lebih tinggi pada kelompok intervensi yang diberikan Pendidikan Kesehatan promosi Kesehatan dibandingkan kelompok kontrol yang tidak diberikan 
pendidikan kesehatan dan promosi untuk skrining pre marital cek up. Pengetahuan dan sikap terhadap pencegahan dan pengendalian thalasemia berat meningkat secara signifikan pada kelompok intervensi. Pendidikan kesehatan jelas meningkatkan kesadaran, motivasi dan meningkatkan pertimbangan skrining untuk pencegahan dan pengendalian talasemia berat pada remaja (Cheng et al, 2018).

Kegiatan PkM ini telah terlaksana dengan baik yang telah didukung melalui keterlibatan para guru dan orang tua yang telah memberi support anaknya untuk mengikuti kegiatan Pkm. Hasil kegiatan PkM yang sudah dilaksanakan diharapkan dapat menjadi rencana tindak lanjut tentang Thalasemia misalnya mengenai cara mengkaji silsilah dalam kelauarga tiga generasi apakah ada yang memiliki keturunan Thalasemia dan melakukan perkawianan sedarah atau tidak, karena hal ini juga dapat berpotensi terjadinya Thalasemia pada remaja usia 13 tahun keatas. Hal ini didukung dengan rekomendasi ahli yang menyatakan pentingnya pencegahan jauh lebih hemat biaya daripada biaya pengobatan jangka panjang dan berlangsung seumur hidup. Pendekatan pencegahan diantaranya yakni membatasi ukuran keluarga bila ada ortu atau salah satu anggota keluarga dengan Thalasemia dengan mengurangi jumlah anak karena bahwa risiko kekambuhan adalah $25 \%$, penyaringan jalur udara potensial (silsilah) keluarga untuk masyarakat umum sehingga perlu dilakukan screening pre marital antara pasangan berisiko tinggi sebelum menikah. Pencegahan lainnya yakni saat hamil dilakukan pemeriksaan prenatal untuk mendeteksi janin apakah memiliki resiko Thalsemia di kemudian hari seperti di beberapa negara maju seperti di Eropa selatan Cina, India, Hong Kong, Taiwan, Iran, dan Singapura (Arian et al, 2020; AbuShaheen et al., 2020; Shivappa et al, 2021,)

Saran dari program PkM ini, diharapkan guru dan tenaga kesehtan mampu bekerjasama dengan orang tua para remaja di tingkat sekolah menengah pertama dan menengah 
atas dalam penyebarluasan informasi mengenai penyakit Thalasemia dan upaya deteksi dini dengan melakukan pemeriksaan pre marital cek up bagi anaknya yang akan melangsungkan pernikahan guna mengurangi resiko memiliki anak Thalasemia baik sebagai carier ataupun Thalasemia Mayor maupun minor. Hal ini sejalan dengan hasil temuan jurnal yang menyatakan bahwa dengan diberikan Pendidikan Kesehatan pada pasangan yang mau menikah dan carier bahwa ada perbedaan statistik yang signifikan dalam skor rata-rata manfaat yang dirasakan, pedoman untuk bertindak, self-efficacy (kemampuan berjuang) jika dikemudaian hari terkena thalassemia sehingga dengan pemberian edukasi dan promosi Kesehatan untuk test pre marital dapat meningkatkan perilaku, dan efikasi diri pasangan yang mau menikah dengan karier betathalassemia (Kia, 2018).

Beberapa orang tua mendampingi anak dan juga sangat antusias mengikuti semua kegiatan yang dilaksanakan. Harapannya dengan adanya peningkatan pengetahuan baik pada remaja maupun keluarga yakni orang tua dan guru yang menjadi support system utama remaja maka akan dapat meningkatkan persepsi, motivasi remaja untuk mengenal dan memahami tentang Thalasemia dan melakukan skrining pre marital medical cek up. Pemberian informasi tentang sesuatu maka ada pengorganisasian, stimulus atau informasi tersebut disusun dalam pola pemikiran masing-masing individu yang dipengaruhi oleh berbagai faktor baik internal maupun eksternal dari remaja $(\mathrm{Ou}$, 2017). Tahapan selanjutnya setelah dilakukan Pendidikan kesehatan yaitu lahirnya interpretasi remaja dalam memberikan arti atau makna tersendiri terhadap stimulus awal yang didapatkan mengenai materi yang diberikan tentang Thalasemia dan promosi Kesehatan tentang pentingnya skrining pre marital cek up sebagai salah satu Tindakan pencegahan. Pengetahuan yang remaja dapatkan akan membentuk persepsi dan sikap. Hal ini dapat disebabkan seseorang dengan tingkat pengetahuan, pemahaman tentang sesuatu akan lebih cenderung memiliki memiliki sikap, 
persepsi yang lebih positif dan baik terhadap materi Pendidikan Kesehatan dan keinginan untuk melakukan skrining.

Pengabdi memberikan saran kepada para remaja untuk berperan aktif dalam mempertahankan kesehatan reproduksi remaja dengan turut serta menyebarluaskan tentang kesehatan mampu membantu menyebarluaskan informasi tentang Thalasemia baik bagi orang tua yang memiliki anak dengan Thalasemia yang masih minim pengetahuan maupun bagi remaja lain ataupun masyarakat luas.

Kegiatan Pkm diharapkan dilakukan Remaja dan kesadaran diri untuk melakukan skrining Thalasemia sebelum menikah sehingga berdampak pada penurunan angka kejadiannya. Profesional kesehatan diharapkan memberikan dukungan pada keluarga terutama informasi, motivasi dan konseling untuk meningkatkan penerimaan kondisi anaknya dengan Thalasemia (Fetriyah, Elasari dan Hernanti, 2016). Hal tersebut juga sudah beberapa negara seperti Iran meningkatkan akses ke perawatan kesehatan sistem Program skrining thalassemia dimulai pada tahun 1997 dan negara lain di kawasan timur tengah yang berkontribusi dalam penurunan angka kelahiran pasien thalassemia mayor. Oleh karena itu, diperlukan kolaborasi antar tenaga kesehatan dan juga dukungan pemerintah untuk kontinu melakukan pendidikan kesehatan dan promosi kesehatan dalam rangka peningkatan kesejahteraan masyarakat. Pentingnya promosi skrining pre marital untuk deteksi dini penyakit genetik, menghindari resiko memiliki anak dengan penyakit genetik seperti Thalasemia, mengurangi masalah psikososial, mengurangi beban keuangan atau ekonomi keluarga (Shakib et al, 2016; Altaany, 2021).

D. KESIMPULAN

Program pengabdian masyarakat dengan judul Health Education Dan Promosi Kesehatan: Thalasemia Dan Deteksi Dini Thalasemia Melalui Pre Marital Cek Up Bagi Remaja di wilayah Banjarmasin melalui webinar di media sosial sangat tepat dilaksanakan karena sesuai dengan kebutuhan masayarakat. Peserta kegiatan PKM 
sangat antusias mengikuti kegiatan, mampu menjawab pertanyaan dari fasilitator dengan antusias, ada peningkatan pengetahuan secara kognitif. Pengabdi memberikan saran kepada remaja untuk melakukan pre marital cek up dan menyebarluaskan informasi tersebut sehingga berkontribusi dalam penurunan kejadian Thalasemia.

\section{DAFTAR PUSTAKA}

Altaany, Z., Khabour, O.F., Alzoubi, K.H.' Alkaraki, A.K.' Al-Taani, G. 2021, The Perception of Premarital Genetic Screening within Young Jordanian Individuals. Public Health Genomics;24:182-188. https://doi.org/10.1159/0005171 $\underline{62}$

Apsari, Nurliana. (2016). Pendampingan Bagi Anak Penyandang Thalasemia Dan Keluarganya. Share Social Work Journal. 6. 10.24198/share.v6i2.13197.

Arian, M., Soleimani, M., FakhrMovahedi, A., Oghazian, M.B., Badiee, Z. 2020. Quality of Life in Patients with Thalassemia Major: A Concept Analysis Using Rodgers' Evolutionary Method. Int J Pediat; 8(5):S 11197-217. DOI: 10.22038/ijp.2019.42126.3547
Cheng, K., Fucharoen, S., Sanchaisuriya, K., Fucharoen, G., Sanchaisuriya, P., \& Jetsrisuparb, A. (2018). Effect of health education on severe thalassemia prevention and control in communities in Cambodia. Archives of public health $=$ Archives belges de sante publique, 76, 13. https://doi.org/10.1186/s13690018-0259-3

Fetriyah, U., Elasari, Y., \& Hernanti, S. (2016). Pengalaman Ibu Merawat Anak Usia Sekolah Dengan Beta Thalassemia Mayor Di Rsud Ulin Banjarmasin. Dinamika

Kesehatan: Jurnal Kebidanan Dan Keperawatan, 7(2), 157171. Retrieved from https://ojs.dinamikakesehat an.unism.ac.id/index.php/dksm/a rticle/view/122

Kia, Nourdin \& Karami, Khdabaakhsh \& Mohamadian, Hashem \& Saki Malehi, Amal. (2018). Evaluation of an educational intervention based on health belief model on beta thalassemia carrier and final suspects couples. Journal of education and health promotion. 7. 77. 10.4103/jehp.jehp_103_16.

Mansjoer, Arif. dkk, 2013, Kapita Selekta Kedokteran Jilid II, FKUI : Jakarta.

Michael Angastiniotis,M., Lobitz, S. 2019. Thalassemias: An Overview. Int. J. Neonatal Screen: $\quad 5, \quad 16$; doi:10.3390/ijns5010016

Ngastiyah, 2013, Perawatan Anak Sakit , Edisi I, Setiawan EGC : Jakarta Ou, Q. (2017). A Brief Introduction to Perception ${ }^{\text {ee }} \quad$ Studies in Literature and Language. Studies in Literature and 
Language. 15

18-28.

http://www.cscanada.net/index.p $\mathrm{hp} / \mathrm{sll} /$ article/view/10055

(Diakses 25 Oktober 2021)

Purba, R. E. J., Nency, Y. M., Farida,H., 2019. Faktor - Faktor Yang Mempengaruhi Pertumbuhan Anak Penderita Talasemia Mayor Di Jawa Tengah, Indonesia Jurnal Kedokteran Diponegoro. Volume 8, Nomor 4, Oktober 2019 Online http://ejournal3.undip.ac.id/inde x.php/medico ISSN Online : 2540-8844

Shakib. A.J., Davoudi-Kiakalaye, A., Pour-Fathollah, A.A., JafariShakib, R., Mohtasham-Amiri, Z. 2016. Health-Related Quality of Life in $\beta$ Thalassemia Major Children in North of Iran. IJBC; 8(4): 108-111.

Shivappa, P., Bernhardt, G.V., Mufti, M.M. and Banu, A. 2021. A Review on Epidemiology and Thalassemia Distribution, in Relevance to United Arab Emirates Population. Journal of Biological Sciences, 21 (2): 280.284 DOI: 10.3844/ojbsci.2021.280.284

Susanto, M. (2020). Edukasi Dan Promosi Kesehatan Thalassemia. Diakses tanggal 18 Oktober 2021.Tersedia Di :Https://Www.Alomedika.Com/ Penyakit/Hematologi/Thalassem ia/Edukasi-Dan-PromosiKesehatan. 